\title{
Analytical Comparison of Composite and Non-Composite through Type and Deck Type Steel Truss Bridges
}

\author{
Abhishek Sharma*, Krishankant Pathak, Pramod K. Singh \\ Department of Civil Engineering, IIT BHU, Varanasi (221005), India
}

Received February 26, 2021; Revised April 4, 2021; Accepted May 23, 2021

\section{Cite This Paper in the following Citation Styles}

(a): [1] Abhishek Sharma, Krishankant Pathak, Pramod K. Singh, "Analytical Comparison of Composite and Non-Composite through Type and Deck Type Steel Truss Bridges, "Civil Engineering and Architecture, Vol. 9, No. 4, pp. 969 - 975, 2021. DOI: 10.13189/cea.2021.090401.

(b): Abhishek Sharma, Krishankant Pathak, Pramod K. Singh (2021). Analytical Comparison of Composite and Non-Composite through Type and Deck Type Steel Truss Bridges. Civil Engineering and Architecture, 9(4), 969 - 975. DOI: 10.13189/cea.2021.090401.

Copyright $\odot 2021$ by authors, all rights reserved. Authors agree that this article remains permanently open access under the terms of the Creative Commons Attribution License 4.0 International License

\begin{abstract}
In trusses, deck type and through type truss systems are generally provided with various member arrangements. To utilize the materials used in the trusses more efficiently, RCC decks are nowadays made composite with the truss members. In this paper, analysis of $72.0 \mathrm{~m}$ deck type and through type, non-composite and composite bridges is presented. The bridges are modelled using STAAD. Pro v8i software with truss members as beam element and deck slab modelled as four noded plate element. The loading on the bridge is done as per the provisions of IRC- 6 and IRC-24. The composite deck effectively reduces the horizontal deflections due to lateral seismic and wind loads in both the truss systems. Decrement in vertical deflection of the truss system was also observed making the structure mode stiffer. Stresses in the members made composite with the deck slab were also reduced and hence resulted in material saving and decreased steel offtake. In the case of composite deck type bridges due to load sharing by the deck slab, the stresses in the top chord are reduced significantly hence eliminating the chances of buckling. Advantages of composite deck are better utilized in deck type bridge system compared to through type bridge system.
\end{abstract}

Keywords Through Type Bridge, Deck Type Bridge, Composite Bridge, Shear Connector, Bridge Stiffness

\section{Introduction}

The most common type of steel bridges are through-type and deck-type bridges. In the through-type bridge system the carriage way is located at the bottom level of the load carrying structure (fig 1(a)), where as in the deck-type system the carriage way is located on the top of load carrying system (fig 1(b)).

In through type truss system, the deck rests on the tension members while on the deck type truss system the deck rests on the compression members. Traditionally the deck is arranged on the stringer beams and is not composite with the truss. In such systems all the load is taken by the steel truss system only. Whereas in composite steel truss bridges, the deck is made composite with the truss members so that the deck starts participating in load sharing

Composite steel truss bridge systems offer an efficient and aesthetic design solution in bridge engineering [1]. In a composite truss, virtues of steel and concrete as construction materials are better utilized. It can prove to be an economical system in medium span bridge construction. Further, composite trusses with HSS members are better suited in continuous bridges with a span longer than $200 \mathrm{~m}[2]$. 


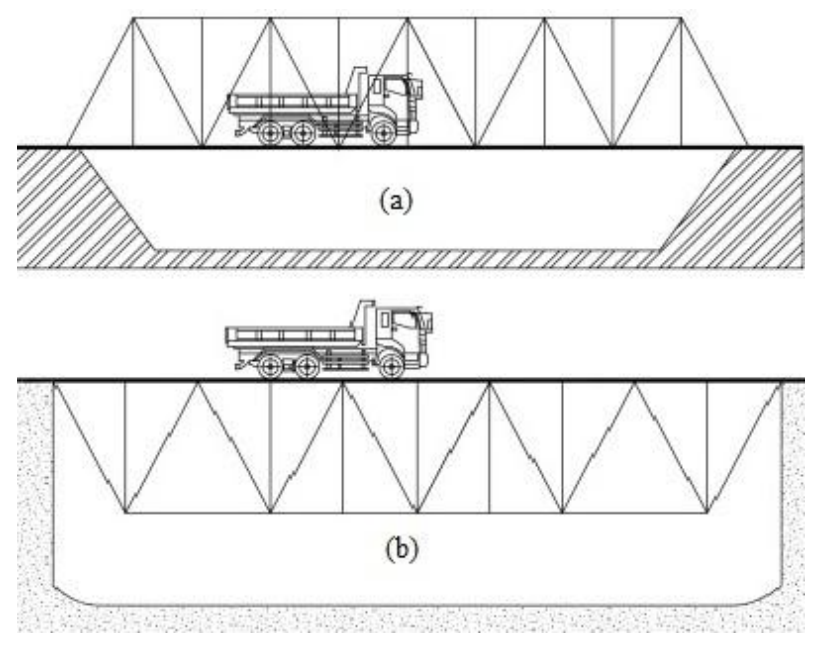

Figure 1. Bridge system (a) Through type truss bridge (b) Deck type truss bridge Shear is transferred between steel truss and concrete deck with the help of shear connectors. (Fig. 2).

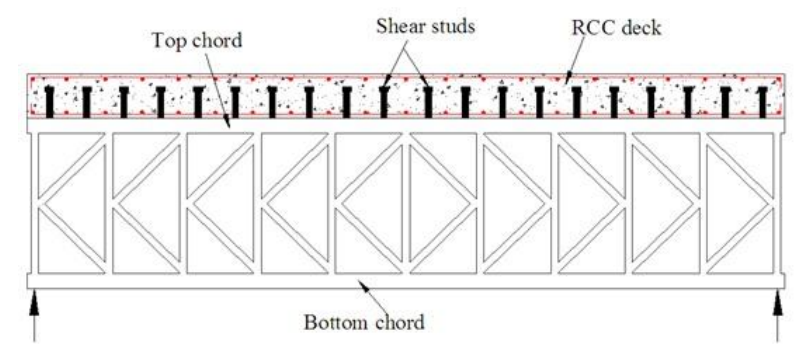

Figure 2. Composite truss bridge

Concrete can carry compression more economically, and therefore, can be used in composite action with the top chord in deck type truss system. The top chord compression members and web compression members of a steel truss will buckle before the tension members reach their ultimate strength. Hence, composite action of the RCC deck slab with the top chord compression members becomes useful in preventing its buckling. Bottom chord tension members and laterally supported top chord compression members of composite truss can take load up to their ultimate strength provided the web compression members are designed with sufficient load factor to prevent their failure [3], [4]. In the Czech Republic twelve simply supported composite truss bridge systems with spans ranging from $21 \mathrm{~m}$ to $63 \mathrm{~m}$ were built in last decade [5]. The Nantenbach Bridge [6] in Germany has a span of 83.2 $\mathrm{m}+208 \mathrm{~m}+83.2 \mathrm{~m}$. It is a composite truss bridge with variable depth. To improve the flexural capacity of the bridge system, concrete slabs are provided between the two bottom chords in the region experiencing hogging. This also improved the balance of weight among side and middle spans.

The failure of a bridge can be catastrophic as it can cause injury or death as well as being be very expensive to restore [7]. In the Chauras bridge uplifting of the side span during deck slab casting caused its failure [8]. Continuous span steel truss bridges can be constructed with the advantage of approximately $1 / 3$ rd mid span sagging moment, and $2 / 3$ rd support hogging moment, of the total simply supported span moment. This type of construction was adopted in case of Chauras and Garudchatti bridges [8], [9]. Three span continuous truss geometry was adopted in these cases, where side to main ratio was kept as 0.364 .

In the continuous composite truss bridge, due to tensile shrinkage strain, and tensile flexural strain under live load condition, cracking of the deck slab at the support sections is unavoidable. Controlling crack growth is an important concern in steel and RCC composite continuous bridges [10]. Harmful substances may enter into the concrete decks through these cracks. Accumulation of water, sulphates, chlorides, and other potentially corrosive agents in the cracks can cause deterioration, leading to larger cracks, spalling, potholes and ultimately reduction of strength of the bridge deck or reinforcing steel, which can make bridge unsafe.

Despite of available methods for crack control viz. use of relatively large amount of rebar, prestressing of the deck in hogging or negative bending moment zone, cracks within the limit of acceptable widths, use of double-deck at top and bottom in continuous composite truss bridge, use of shear pockets and precast deck slab, deck flexing and thermal prestressing methods have been tried an effective and feasible method has yet to be identified for steel RCC composite structures [11]. Therefore, simply supported medium span $(30 \mathrm{~m}$ to $100 \mathrm{~m})$ deck type composite truss bridges are most suitable, especially for deep valley condition in mountainous regions.

Experimental investigations on composite trusses begin in the mid 1960's mainly in USA and Canada. Initial experiments were focused on testing such structures or buildings. The experimental results led to design recommendations and specification of the American Society of Civil Engineers [12].

Composite construction of RCC floors with trusses is common in case of building construction, and with steel plate girders in case of composite plate girder bridges. There is no direct literature available for capacity calculation of the composite steel truss bridges in plastic stage [8]. Despite unavailability of proper design guidelines and design standards for composite truss bridges, various types of composite truss bridges have been constructed in the World. Design of the bridge at collapse in plastic condition is carried out as per provisions given for composite truss and OWSJ for buildings in CISC 2003 [13] and ASCE Task Committee on Design Criteria for Composite Structures in Steel and Concrete (1996).

In Eurocode 4 [14], discusses formulae for local effect of a concentrated longitudinal force and the distribution of the longitudinal shear force into local shear flow between steel section and concrete slab. But design recommendations for the design of composite truss bridges is not presented. In Indian code IRC: 22-2015 [15] for steel concrete composite construction, no separate provisions are made for the design of composite truss bridges. 


\section{Modelling and Analysis of Bridges}

Typical non-composite and composite truss bridges with through type truss system and deck type truss system are designed and compared (fig.3). In the case of non-composite bridge, all loads are carried by the steel truss and deck slab is not structural component of the bridge. In the composite bridge it is assumed that the deck also participates in the load sharing along with the truss members.

The two bridges have been designed following detailed procedure given below under various loading conditions as per Indian codes IRC: 6-2017 [16] and IRC: 24-2001 [17]. Design using STAAD Pro. V8i software.

A 3D space frame model is prepared using STAAD Pro. V8i software for the analysis of the $72 \mathrm{~m}$ span truss bridges, for non-composite bridges the deck slab is not considered as structural element in the model and the weight of the slab is distributed on the connecting points of the stringer beams. For composite type bridges, 4-noded plate elements are used to model deck slab which is connected with the adjacent truss member. Section builder is used for generating built up sections.

Geometric details of the $72 \mathrm{~m}$ span bridge model are given below.

i. Height of Truss (C/C distance between top chord and bottom chord members) $=8.0 \mathrm{~m}$.

ii. $\quad \mathrm{C} / \mathrm{C}$ distance between two trusses $=7.0 \mathrm{~m}$

iii. Width of roadway $=5.5 \mathrm{~m}$

iv. Number of $3 \mathrm{~m}$ top panels $=24$

v. Number of $6 \mathrm{~m}$ bottom panels $=10$

vi. $\quad \mathrm{C} / \mathrm{C}$ distance between cross girders $=3 \mathrm{~m}$
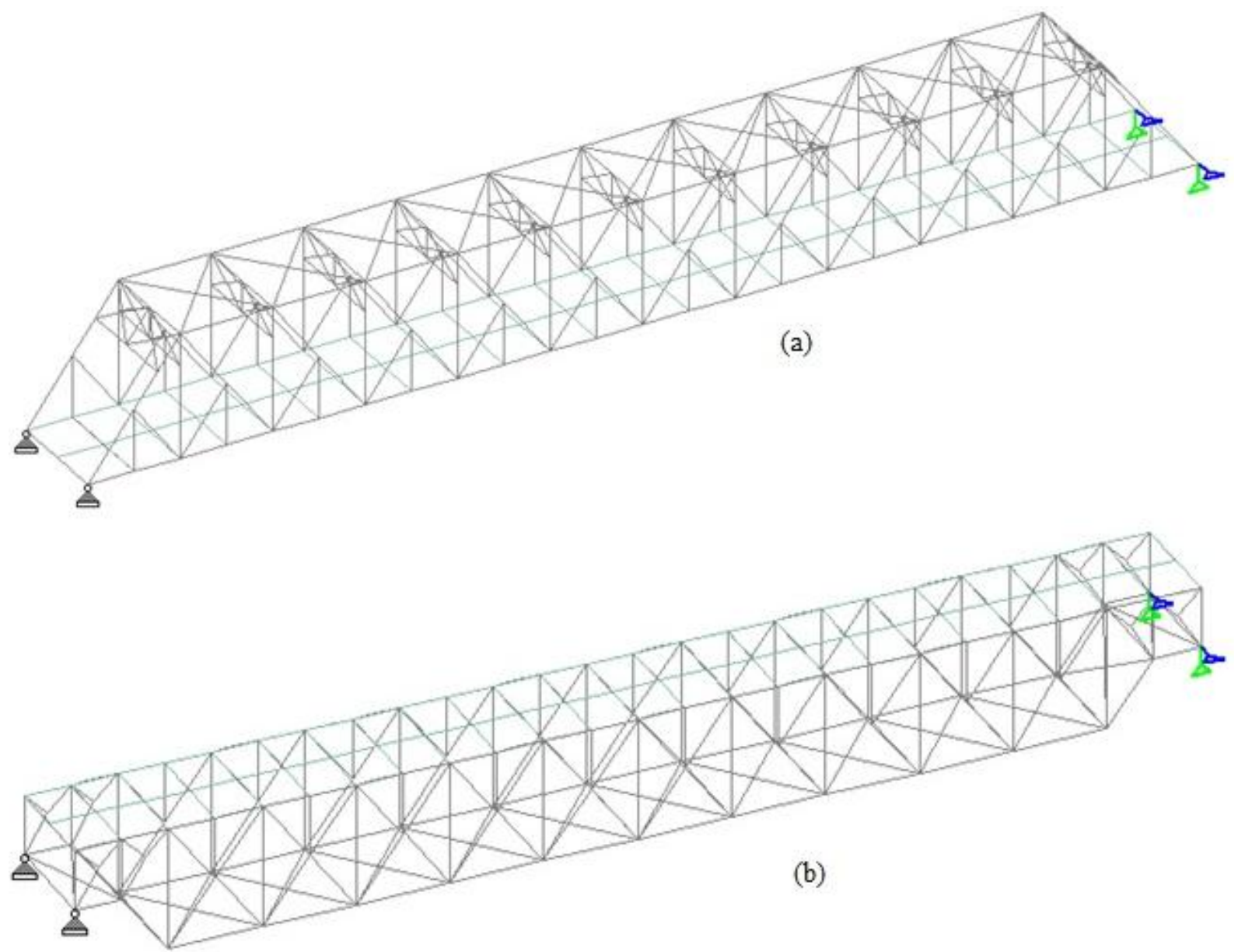

Figure 3. STAAD model for (a) Through type $72.0 \mathrm{~m}$ span bridge (b) Deck type $72.0 \mathrm{~m}$ span bridge 
M40 grade concrete is used in the deck slab. E250 grade mild steel having yield stress of $250 \mathrm{~N} / \mathrm{mm}^{2}$ is used with the following properties.

Young's modulus of elasticity, Es $=2.11 \times 105 \mathrm{~N} / \mathrm{mm} 2$

Poisson's ratio $=0.3$

Shear modulus $=77 \times 103 \mathrm{~N} / \mathrm{mm}^{2}$

Coefficient of thermal expansion $=1.17 \times 10-5 /{ }^{\circ} \mathrm{C}$

After modelling, analysis has been carried out using STAAD Pro. v8i.

Following primary loads and load combinations are considered on the bridge.

a) Primary loads

Primary loads considered for the analyses are given in Table 1.

\section{b) Load Combination}

Following load combinations (Table-1, IRC: 6-2014) using the above primary loads are considered to generate the envelope of forces for steel design using STAAD Pro.

Table 1. Primary Loads

\begin{tabular}{|c|c|c|}
\hline $\begin{array}{c}\text { Load } \\
\text { no. }\end{array}$ & Name & Remark \\
\hline 1 & EQZ & EQ in transverse direction \\
\hline 2 & EQX & EQ in longitudinal direction \\
\hline 3 & SW & $\begin{array}{c}\text { Self-weight of truss members including } 20 \% \text { extra for } \\
\text { lacings gussets plates }\end{array}$ \\
\hline 4 & SL & $\begin{array}{c}3.5 \mathrm{kN} / \mathrm{m} 2 \text { extra load during deck slab casting due to } \\
\text { shuttering and equipment. }\end{array}$ \\
\hline 5 & DS & $\begin{array}{c}\text { Wt. of av. 225mm thick deck slab and wearing coat } \\
\text { applied on top chord and stringers as distributed } \\
\text { longitudinally }\end{array}$ \\
\hline 6 & CB & $\begin{array}{c}\text { Load due to crash barrier on top chord members as } \\
\text { UDL }\end{array}$ \\
\hline 7 & WL & Wind load in transverse direction $\left(2.0 \mathrm{kN} / \mathrm{m}^{2}\right)$ \\
\hline 8 & FPLL & $4.0 \mathrm{kN} / \mathrm{m} 2$ load on Foot path. \\
\hline 9 & DL & $1.2 \times S W+D S+W C+C B$ \\
\hline 10 & LL & LL as per IRC: 6-2010 \\
\hline
\end{tabular}

i. Service condition

Under service condition design is carried out for - [DL + LL] case.

During service condition, DL includes self-weight of truss and deck slab, and super imposed dead load. Maximum live load effects are taken in the combination.

\section{ii. Construction stage}

Launching of the truss is assumed to have been safely carried out using false pier or launching nose etc., as the case may be. Safety of the truss during deck slab casting has to be checked with self-weight, deck slab, shuttering and equipment loads, for which additional load factor of 1.5 is recommended. For the $1.5 \times[\mathrm{DL}+\mathrm{SL}]$ case, $30 \%$ increase in permissible stress as per cl. 202.3 of IRC: 6-2014 is taken.
In the construction stage, design is checked for (1.5/1.3)x [DL + SL] condition.

iii. Seismic load condition

Design is checked under seismic load, for longitudinal and transverse seismic cases with $20 \%$ live load (cl. 202.3, IRC: 6-2014) and permissible increase in stress of $50 \%$ (cl. 202.3, IRC: 6-2014).

In seismic condition design is checked for - (1/1.5) $\mathrm{x}$ $[\mathrm{DL}+0.2 \mathrm{xLL}+\mathrm{EQZ/EQX}]$ condition.

iv. Wind load condition

Design is checked under wind load condition, for transverse wind load case with full live load (cl 202.3, IRC: 6-2014) and permissible increase in stress of $33 \%$ (cl 202.3, IRC: 6-2010).

In wind load condition design is checked for - (1/1.33) $\mathrm{x}[\mathrm{DL}+\mathrm{LL}+\mathrm{WL}]$ condition.

v. Envelope of forces

The bridge is analysed in STAAD Pro as space frame using its 3D model. Envelops for different load combinations are created and envelopes corresponding to the most critical load combinations are used for design of the bridge.

\section{Typical Design of Composite Truss Bridge}

Design of the bridge is carried out for serviceability condition as per IRC: 24-2010. In the serviceability condition, a fatigue factor of $1 / 1.5$ is used in the permissible stress in steel.

\subsection{Tables}

A typical design example for $72.0 \mathrm{~m}$ span non-composite steel truss bridge is given below. 2-D figures of through type and deck type bridges are shown in figure 4 .

\subsection{Loading on the Bridge}

Following primary loads on the bridge are considered.

\subsubsection{Dead load}

1. Self-weight of the truss is taken by SELFWEIGHT command in STAAD. Additional $10 \%$ weight due to gusset plate, lacings, batten plates and rivets or bolts are included in the self-weight.

2. Load due to deck slab.

Thickness of deck slab is $250 \mathrm{~mm}$ at center and uniformly decreases to $200 \mathrm{~mm}$ towards curb. Therefore, average thickness of the deck slab is taken as $225 \mathrm{~mm}$.

Deck slab is resting on stringers, cross girders and top chord members. Loads from the deck slab are primarily 
taken as UDL on top chord members and stringer beams.

\section{Load due to wearing coat.}

Wearing coat is $56 \mathrm{~mm}$ thick and its unit weight is taken as $22 \mathrm{kN} / \mathrm{m}^{3}$.

\section{Self-weight of crash barrier}

Cross sectional area of the crash barrier is $0.27 \mathrm{~m} 2$ and loading on top chord member due to this is taken as 7.5 $\mathrm{kN} / \mathrm{m}$

5. Temporary load due to shuttering and equipment

During casting of the deck slab, temporary load due to shuttering and equipment is taken as $3.5 \mathrm{kN} / \mathrm{m}^{2}$ (cl. 202.3 IRC: 6-2014).

\subsubsection{Live load}

The bridge is analyzed for two trains of single lane Class-A wheeled vehicles running parallel as per IRC: 6-2014.

\subsubsection{Wind load}

Wind pressure is taken as $2.0 \mathrm{kN} / \mathrm{m}^{2}$ on exposed area of bridge across wind direction as per cl. 209.3 of IRC: 6-2014.

\subsubsection{Seismic Load}

Seismic loading on the bridge is taken for seismic zone-V as per cl. 219 of IRC: 6-2014.

\section{Results and Discussion}

In the case of continuous composite steel truss bridges hogging moment at the supports is approximately twice the sagging moment, and under tension the top composite deck cracks without any significant advantage, which has been main disadvantage in the design of continuous composite steel truss bridges.

For serviceability condition, the load is taken as $(\mathrm{DL}+\mathrm{LL})$, and in the permissible stresses a fatigue factor of $1 / 1.5$ is used. Deflection, stress and steel off take for the non-composite and composite bridges in service condition are given in Table 2.

From Table 1 following inferences can be drawn

- In seismic condition, due to composite action of the deck slab for the through type bridge, maximum horizontal deflection in the top chord at the mid span decreases from $180.6 \mathrm{~mm}$ to $9.3 \mathrm{~mm}$ by $94.8 \%$. Similarly for the deck type bridge maximum deflection occurring in the bottom chord in the mid span in decreases form $173.5 \mathrm{~mm}$ to $18.1 \mathrm{~mm}$ by $89.6 \%$.

In the wind load condition due to composite action of the deck slab for the through type bridge, maximum horizontal deflection in the top chord at the mid span decreases from $127.3 \mathrm{~mm}$ to $10.9 \mathrm{~mm}$ by $91.4 \%$. Similarly for the deck type bridge maximum deflection occurring in the bottom chord in the mid span decreases form 132.9 $\mathrm{mm}$ to $22.6 \mathrm{~mm}$ by $83.0 \%$.

The horizontal deflection is considerably reduced by making the deck composite in both deck type and through type bridge systems.

- For through type bridge, the vertical deflection at the mid span decreases from $161.0 \mathrm{~mm}$ to $126.9 \mathrm{~mm}$ by $21.2 \%$. Similarly for the deck type bridge maximum deflection occurring in the bottom chord in the mid span decreases form $177.0 \mathrm{~mm}$ to $143.1 \mathrm{~mm}$ by $19.1 \%$.

- In the through type bridge maximum stress in the bottom chord at the mid span decreases from 159.6 $\mathrm{N} / \mathrm{mm} 2$ to $53.7 \mathrm{~N} / \mathrm{mm} 2$ by $66.4 \%$ for the composite case. Similarly for the deck type bridge maximum stress in the top chord at the mid span decreases from $165.6 \mathrm{~N} / \mathrm{mm} 2$ to $56.7 \mathrm{~N} / \mathrm{mm} 2$ by $65.8 \%$ for the composite case

Steel offtake for the composite bridge is $1883 \mathrm{kN}$ and $1805 \mathrm{kN}$ for through type and deck type truss system respectively, and steel offtake for the non-composite bridge is $1981 \mathrm{kN}$ and $1954 \mathrm{kN}$. Thus, it is seen that composite construction is economical for both the bridge types

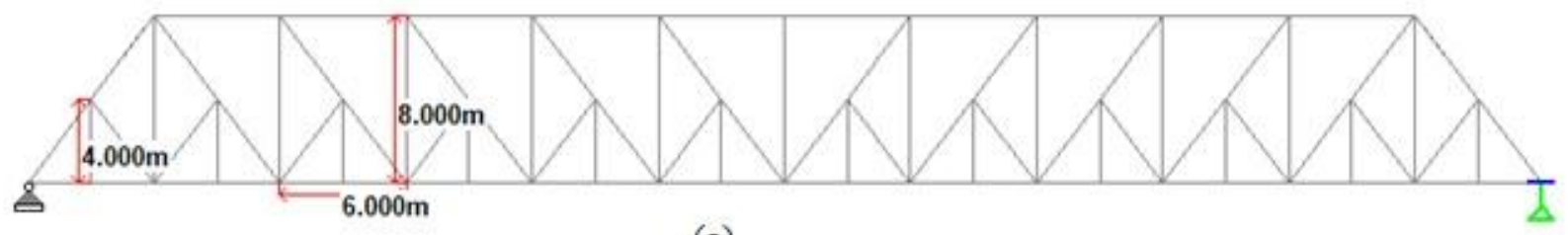

(a)

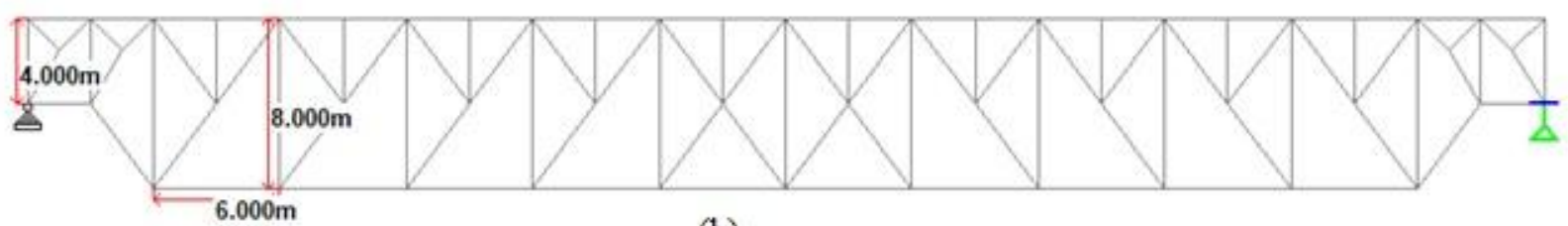

(b)

Figure 4. Two alternatives of $72.0 \mathrm{~m}$ truss bridge 
Table 2. Deflection, stress and steel offtake

\begin{tabular}{|c|c|c|c|c|c|}
\hline & & \multicolumn{2}{|c|}{ Through type truss system } & \multicolumn{2}{|c|}{ Underslung truss system } \\
\hline & & Composite deck & $\begin{array}{l}\text { Non-Composite } \\
\text { deck }\end{array}$ & Composite deck & $\begin{array}{c}\text { Non-Composite } \\
\text { deck }\end{array}$ \\
\hline \multirow{3}{*}{$\begin{array}{l}\text { Vertical deflection in } \\
\qquad \mathrm{mm}\end{array}$} & $\begin{array}{l}\text { Deflection under } \\
\text { dead load } \\
\text { (SW+SIDL) }\end{array}$ & 75.6 & 92.4 & 86.2 & 103.6 \\
\hline & $\begin{array}{l}\text { Deflection under } \\
\text { live load } \\
\end{array}$ & 51.3 & 68.6 & 56.9 & 73.4 \\
\hline & Total deflection & 126.9 & 161 & 143.1 & 177 \\
\hline \multirow{2}{*}{$\begin{array}{l}\text { Horizontal deflection in } \\
\qquad \mathrm{mm}\end{array}$} & $\begin{array}{l}\text { Deflection due to } \\
\text { seismic load }\end{array}$ & 9.3 & 180.6 & 18.1 & 173.5 \\
\hline & $\begin{array}{l}\text { Deflection due to } \\
\text { wind load }\end{array}$ & 10.9 & 127.3 & 22.6 & 132.9 \\
\hline \multirow{3}{*}{ Stress in $\mathrm{N} / \mathrm{mm} 2$} & $\begin{array}{l}\text { Max stress in top } \\
\text { chord }\end{array}$ & 162.6 & 160.5 & 56.7 & 165.6 \\
\hline & $\begin{array}{l}\text { Max. stress in } \\
\text { bottom chord }\end{array}$ & 53.7 & 159.6 & 176.6 & 175.7 \\
\hline & $\begin{array}{l}\text { Max. stress in } \\
\text { deck slab }\end{array}$ & 7.7 & - & 8.1 & - \\
\hline \multicolumn{2}{|c|}{ Steel offtake as per STAAD model in $\mathrm{kN}$} & 1883 & 1981 & 1805 & 1954 \\
\hline
\end{tabular}

\section{Conclusions}

From the analytical study comparing the effects of composite and non-composite decks in through type and deck type steel truss systems, the following conclusions are drawn.

1. Buckling of the top chord members in the deck type bridge is prevented by the composite RCC deck. Stress is the top chord member at the mid span is reduced from $165.6 \mathrm{~N} / \mathrm{mm} 2$ to $56.7 \mathrm{~N} / \mathrm{mm} 2$ by $65.8 \%$. The composite RCC deck also prevents sudden buckling of the top chord members in case of any over load.

2. The horizontal deflection of the bridge for the composite through type decreases by $94.8 \%$ and by $89.6 \%$ for the deck type bridge under seismic load. Similarly horizontal deflection of the bridge for the composite through type decreases by $91.4 \%$ and by $83.0 \%$ for the deck type bridge under wind load

3. Vertical deflection in the service condition for the through type bridge decreases form $161.0 \mathrm{~mm}$ to $126.9 \mathrm{~mm}$ by $21.2 \%$. Similarly it decreases from $177.0 \mathrm{~mm}$ to $143.1 \mathrm{~mm}$ by $19.1 \%$ for deck type bridge.

4. In the through type bridge maximum stress in the bottom chord at the mid span decreases by $66.4 \%$ for the composite case. Similarly for the deck type bridge maximum stress in the top chord at the mid span decreases by $65.8 \%$ for the composite case

5. Maximum Stress in the concrete slab at the mid span is $7.7 \mathrm{~N} / \mathrm{mm} 2$ for through type bridge and it is 8.1 $\mathrm{N} / \mathrm{mm} 2$ for deck type bridge.

6. Steel offtake in the through type bridge reduces from $1981 \mathrm{kN}$ to $1883 \mathrm{kN}$ by $4.9 \%$ for the composite case.
For the deck type composite bridge it reduces from $1954 \mathrm{kN}$ to $1805 \mathrm{kN}$ by $7.62 \%$.

Significantly high proportion of the compressive force in the top members of a deck type bridge is shared by the deck slab, while preventing buckling of the steel members. Composite deck also significantly increases horizontal stiffness of the bridge resulting in more economical design of the bridge. Vertical deflection of the composite bridges is also lower in comparison to the non-composite bridges, resulting in its better serviceability.

\section{REFERENCES}

[1] Reis, A. J. "Bridge decks: composite systems for improved aesthetics and environmental impact". Proc. 3rd Int. Meeting on Composite Bridges, pp. 645-59, Madrid, 2001.

[2] Zhijuan Tian, Yongjian Liu, Lei Jiang, Weiqing Zhu, Yinping Ma, "A review on application of composite truss bridges composed of hollow structural section members". Journal of traffic and transportation Engineering (English edition) pp 94-108, 2019.

[3] Azmi, M. H., 'Composite Open-Web Trusses with metal Cellular Floor', Master of Engineering thesis, McMaster University, Hamilton, Ontario, April, 95 p, 1972.

[4] Shao, X.D., "Beam-type Composite Structure Bridge". China Architecture and Building Press, Beijing, 2015.

[5] Machacek, J. and Charvat, M., "Design of Shear Connection between Steel Truss and Concrete Slab", 11th International Conference on Modern Building Materials, Structures and Techniques, MBMST 2013, Procedia Engineering, 57, pp. 722-729, Elsevier, 2013. 
[6] Kang, C.J., Schneider, S., Wenner, M., et al.,. Development of design and construction of high-speed railway bridges in Germany. Engineering Structures 163, 184-196 2018.

[7] Isa Sani Mohammed, Anas Muhammad, Bashir Mohammed, "Determining Measures Enhancing Bridges Maintenance Practice in Nigeria," Civil Engineering and Architecture, Vol. 8, No. 4, pp. 391 - 403, 2020. DOI: 10.13189/cea.2020.080401

[8] Birajdar, H. S., Maiti, P. R. and Singh, P. K.. "Failure of Chauras Bridge." Engineering Failure Analysis, Elsevier, Vol. 45, pp. 339-346 2014.

[9] Birajdar, H. S., Maiti, P. R. and Singh, P. K. "Strengthening of Garudchatti Bridge after Failure of Chauras Bridge." Engineering Failure Analysis, Elsevier, Vol. 62, pp. 49-57, 2015.

[10] He, J., Liu, Y., Chen, A., and Yoda, T. "Experimental study on inelastic mechanical behaviour of composite girders under hogging moment", Journal of Constructional Steel Research, 66, 37-52, Elsevier, 2010.

[11] Kim, S. H., Kim, J. H., Ahn, J. H. and Song, H. W. "An analytical investigation of thermal prestressing method for continuous composite girder bridges", Magazine of Concrete Research, 59, No. 3, 165-178, 2007.

[12] ASCE Task Committee on Design Criteria for Composite Structures in Steel and Concrete, "Proposed Specification and Commentary for Composite Joists and Composite Trusses, ASCE, Journal of Structural Engineering, 122 (4) 1996.

[13] Canadian Institute of Steel Construction (CISC), Handbook of Steel Construction, CAN/CSA S16.1 94, Section 16, "Open-Web Steel Joists", 7th Edition, Willowdale, Ontario 2003.

[14] ENV 1994-2 Eurocode-4: Design of composite steel and concrete structures, Part 2: Composite bridges. CEN 1997.

[15] IRC:22-2015, "Standard Specifications and Code Of Practice for Road Bridges-Section VI (Composite Construction)", Indian Road Congress, India, 2015.

[16] IRC: 6-2017, 'Standard specifications and code of practice for road bridges', Section II, Loads and Stresses, India, 2017.

[17] IRC: 24-2010, Standard specifications and code of practice for road bridges, Section V, Steel road bridges, India, 2010. 